\section{強いストレス経験がその後の恐怖条件づけを 増強させる生理学的基盤}

$\bigcirc$ 領家 梨恵 (東北大学加齢医学研究所)

戦争，レイプや大きな自然災害といった生死を左右 するような強い心理的負担は，価值観をネガティブな 方向に変え, 身体的不調の慢性化を引き起こす。強い ストレスを経験した 1 か月以上経過してもなお不調が 改善されない場合は心的外傷後ストレス障害（PTSD） と診断される。ストレッサーに曝された動物も同様に, PTSD に呈される精神不安状態や生理学的異常と類似 した症状を示すことから, 動物モデルとしての応用が 期待されている。

\section{恐怖条件づけを用いた PTSD 動物モデルの作成}

複数回のフットショックのような強いストレスに曝 された経験のある動物では, 後の恐怖条件づけが増強 される現象（条件性恐怖反応増強効果）が知られてい る（Rau et al., 2005）。本研究では，フットショック（1 $\mathrm{mA} \times 4$ 回）と強制水泳（20 分間）を合わせた複合ス トレスをラットに与えることで PTSD モデル動物を作 成した。このモデル動物を用いて, 恐怖反応の強度を 評価するために，無条件刺激として下肢への電気ショ ック（0.1 mA×2 回）を与え, 電気ショック装置や音 や照明などを含む環境を条件刺激とした，電気ショッ クと文脈の連合学習である文脈恐怖条件づけを用いた。 条件反応である freezing（呼吸以外の体動を示さない） を記憶の指標とした。ラットが複合ストレスを受けた 2 週間後に文脈恐怖条件づけを行い, その後, 文脈恐 怖条件づけの保持テストを断続的に 2 週間検討するこ とで，長期間保持される条件性恐怖反応を明らかにし た（Ryoke et al., 2014）。PTSD の特徴的診断基準である 数力月ないしは数年後までも続く症状を再現した。

\section{条件性恐怖反応増強化の生理学的メカニズム}

次に, 強いストレス経験が恐怖反応を増強させるに 至る生理学的メカニズムを検討することを目的とした。 主要なストレス反応である視床下部一下垂体一副腎皮 質（HPA）系および交感神経系に注目した。HPA 系お よび交感神経系の活性は代表的なストレス反応であり， 情動行動の表出や情動記憶・学習への深い関与が多く の研究で指摘されている (Adamec et al., 2007;
Roozendaal et al., 2004)。そこで，複合ストレス曝露に よる HPA ストレス反応系の最終産物であるグルココ ルチコイドおよび，交感神経系の神経伝達物質である アドレナリンとノルアドレナリン活性化の影響を検討 した。強いストレス経験の学習におけるグルココルチ コイド，アドレナリンおよびノルアドレナリンの関与 を検討するため，グルココルチコイドの合成阻害薬ま たは $\beta$ アドレナリン受容体拮抗薬を複合ストレス前に 腹腔内投与することで，一時的に強いストレス経験時 のラットのストレス反応系を抑制した。しかし，グル ココルチコイド合成阻害のみだと，複合ストレスの文 脈記憶の保持阻害は示唆されたものの，条件性恐怖反 応増強効果には影響しなかった。複合ストレスが引き 起こす条件性恐怖反応増強効果の形成に, 両ストレス 経路が相補的に作用していることが明らかとなった。

\section{結 語}

複合ストレスという強いストレス経験は, 弱い刺激 に過剰に反応し，恐怖条件づけの長期間にわたる保持 を引き起こした。その背景には，HPA 系と交感神経系 のストレス反応が関与しており，ストレスを受けた際 に引き起こされるストレス反応の程度が後の恐怖条件 づけにおける条件づけされやすさを決定していると考 えられる。今後はストレス反応により変化する神経回 路や細胞内力スケードのようなより細かいレベルの解 析を行い, PTSD 発症メカニズムを検討する必要があ るだろう。

\section{引用文献}

Adamec, R. et al. (2007). Involvement of noradrenergic and corticoid receptors in the consolidation of the lasting anxiogenic effects of predator stress. Behavioural Brain Research, 179(2), 192-207.

Roozendaal, B., McReynolds, J. R., \& McGaugh, J. L. (2004). The basolateral amygdala interacts with the medial prefrontal cortex in regulating glucocorticoid effects on working memory impairment. The Journal of Neuroscience, 24 (6), 1385-1392.

Ryoke, R., Yamada, K., \& Ichitani, Y. (2014). Long-term effects of traumatic stress on subsequent contextual fear conditioning in rats. Physiology \& Behavior, 129, 30-35. 


\section{条件反応にみる知・情・意}

○沼田 恵太郎 (大阪大学大学院人間科学研究科)

「パヴロフの犬」で知られる古典的条件づけ研究は, 1960 年代以降, 認知心理学的な視点から再解釈される ようになった (中島, 2014, 基礎心理学研究, 33, 36-47)。 本発表では皮膚電気条件づけの実験事態について概観， 先行研究と実験データに基づき, 心理学の主な関心で ある「知・情・意」に関する議論を紹介した。

\section{研究 I：条件反応は何を反映しているか?}

皮膚電気活動を指標とした古典的条件づけ事態では, 刺激間間隔が 8 秒など比較的長い場合, 条件刺激の呈 示中に複数の峰をもつ複合反応が生起する（古武・ 多河, 1951, 心理学研究, 22,1-6)。複合反応は注意や 予期などの情報処理を反映し, 条件づけと認知の関係 を探る手がかりになると考えられている(沼田・宮田,

2011，人文論究，61(2)，55-88）。例えば, 図形を条件 刺激, 手首一の電撃を無条件刺激とした分化条件づけ $(N=40)$ を 8 試行行うと, 図 1 に示すように, (1) $1-2$ 試行目の時点で $\mathrm{CS}+/ \mathrm{CS}$-の分化が生じる。興味深 いことに (2) 条件刺激の呈示から 1-4秒の間に生じる FIR（第一間隔反応）は試行経過に伴い減弱，（3）4-9 秒の間に生じる SIR（第二間隔反応）が出現する。FIR は条件刺激一の注意, SIR は無条件刺激の予期を反映 すると考えられており, 後者は（4）試行経過で SIR の出現が遅れる「延滞制止」によっても支持される。

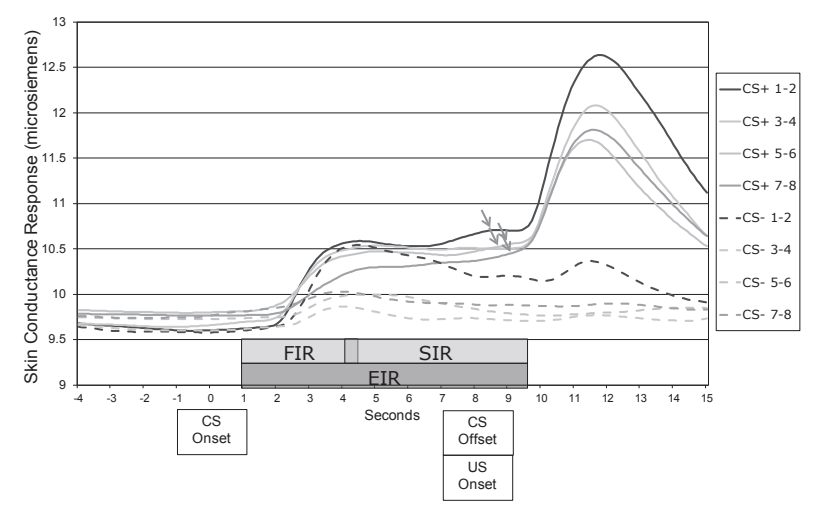

図1. 条件反応の獲得 ( 2 試行毎に平均したもの)

\section{研究 II：不安は条件づけを促進するか？}

情動性と条件づけの個人差を巡る問題は, 学習研究 の主要な興味の 1 つである。例えば, 条件反応の形成 に関しては, 不安が条件づけを促進する不安促進説
(Orr et al., 2000, J Abnorm Psychol, 109, 290-298) と不安 が条件づけを妨害する不安妨害説（Davis et al., 2000, Contemporary issues in modeling psychopathology 113142）の 2 つの立場が存在する。神経症傾向は不安障害 のリスク因子と考えられるが, 不安水準が恐怖の獲得 にどのように影響するかは明らかにされていない (Kindt \& Soeter, 2014, PLoSOne, 9, 1-6)。例えば，20 秒 間呈示される図形を条件刺激, 手首一の電撃を無条件 刺激とした分化条件づけ $(N=37)$ を 2 試行行うと, 図 2 に示すように, 状態不安（清水・今栄, 1981, 教育 心理学研究，29, 62-67）が高い群で低い群より FIR は 大きくなる。この知見は不安促進説を支持しており， 不安が条件刺激への注意と関連することを示唆する。

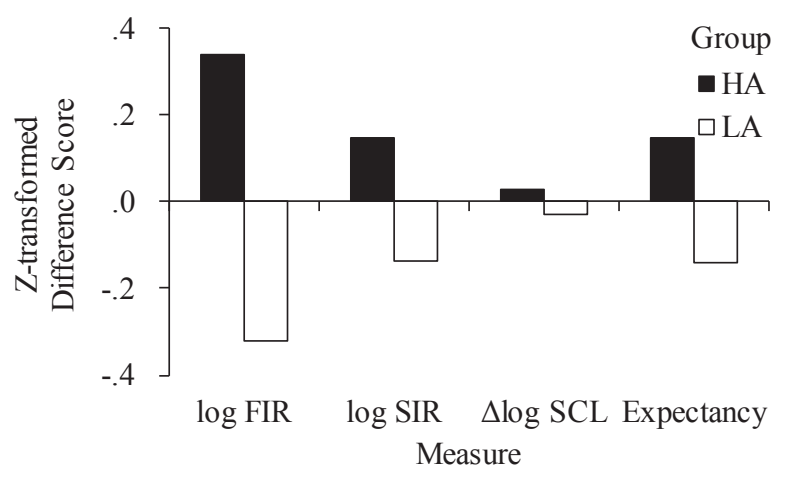

図 2.2 試行目の分化量 $(\mathrm{CS}+/ \mathrm{CS}$ 一の差分を $\mathrm{Z}$ 得点化 $)$

\section{研究正：言語教示が恐怖条件づけに与える影響}

複合条件づけを行った後に，一方の要素刺激のみを 強化すると，他方の要素刺激に対する条件反応は減弱 する。この現象は逆行阻止と呼ばれ，「生活体がいかに 情報の取捨選択を行うか」という疑問を解決するため, 盛んに研究されてきた経緯がある。逆行阻止の生起に 関しては, 古典的条件づけ研究で発展した連合学習説 (Dickinson \& Burke, 1996, QJ Exp Psychol, 37, 397-416) 之, 原因帰属を端緒と寸る命題推論説 (De Houwer, 2009, Learn Behav, 37, 1-20）の2つの立場がある。前者は経 験により「そこにあるはず」の刺激が想起されること で, 後者は教示や経験によって獲得したルールが組み 合わされることで, 標的刺激の阻止が生じると考える。 沼田 (2015, 日本感情心理学会) は研究 II の実験課題 を拡張, 結果の加算性に関する教示を与えると逆行阻 止が強まることを示し，命題推論説を支持している。

以上の知見は，ヒ卜を対象とした古典的条件づけ 研究の広がりを示寸ものであると考えることができる。 
条件づけ課題における不快事象回避の行動特性と生理 活動の関係の検討 一計算論モデル・研究領域基準 （RDoC）を通した精神医学への貢献に向けて一

$\bigcirc$ 片平 健太郎（名古屋大学大学院環境学研究科）

近年, 精神医学の研究方略に二つの変革が起ころう としている。一つは研究領域基準 (Research Domain Criteria, RDoC）とよばれる, 従来の診断カテゴリーに とらわれず行動や神経生物学的指標にもとづいて精神 障害を研究しようという新たな枠組みが提案されたこ とである。もう一つは, 計算論的精神医学という, 計 算論モデリングの手法を取り入れた研究領域が作られ つつあることである。本講演では心拍変動に関する研 究を事例として紹介しながら，それらの枠組みや方法 論が生理心理学から精神医学をつなぐ上でどのような 役割を担うかを議論する。

\section{研究領域基準 (RDoC)について}

従来の精神医学における基礎研究では, DSM や ICD 等の診断マニュアルにより個人を臨床群と対照群 に分類し, 群間の比較をするという方略が用いられる ことが多かった。そのような研究法については, 疾患 カテゴリーと生物学的基盤が一対一に対応していない, 同一カテゴリー内の個人でも症状に非一様性がある, またそれらの制約により, 基礎研究で得られた生物学 的知見が臨床応用に直結しない, 等の問題が指摘され ていた。そのような背景のもと, National Institute of Mental Health (NIMH) により 2009 年に提案された新 たな研究上の方略をまとめたものが RDoCである。今 年になり, 論文誌 Psychophysiology に RDoC に関する 特集号が組まれたことからも（Patrick \& Hajcak, 2016）, 生理心理学分野の研究者における RDoC に対寸る関心 の高まりがうかがえる。RDoC の特徵の一つは，精神 障害を記述するために RDoCマトリックスを構築する ことである。 RDoC マトリックスの各行はコンストラ クト（構成概念）を表し, 各列は分析単位（units of analysis）を表す。構成概念の例として, 例えばドメイ ン“Negative Valence System”の中に, “Acute Threat”, “Potential Threat” 等がある。分析単位には「遺伝子」, 「分子」,「細胞」,「神経回路」,「生理」,「行動」,「自 己報告」,「実験パラダイム」がある。 NIMH のウェブ ページ上には, 各コンストラクトの分析単位として想
定される項目が例として挙げられている。例えば “Reward Learning”というコンストラクトの分析単位で ある「生理」にはエラー関連電位等の事象関連電位も 挙げられている。

\section{心拍変動と計算論モデル}

心拍変動の高周波領域は副交感神経の活動を反映し, 安静時のそれが強い個人ほど抑制性の感情制御が強い ことが知られている。このような生理活動の個人差は, 快情動または不快情動を喚起するような事象を経験し たときのその後の行動とまで関連があるのだろうか。 そのような問題意識のもと, Katahira et al. (2014) は, 快画像, 不快画像が選択の結果として呈示される確率 的学習課題を用い, その選択行動データから強化学習 モデルのパラメータを推定することで個人の行動特性 を定量化した。その結果, 不快画像を回避する傾向を 表すパラメータの值と安静時の心拍変動に負の相関が 認められた。これは心拍変動が小さい個人ほど不快画 像を避ける傾向が強いことを示している。この研究で 得られた知見は, RDoC マトリックス上のコンストラ クトでは“Acute Threat”に関連し，分析単位として「生 理」に心拍変動，「行動」に回避，「パラダイム」に情 動画像を結果とする確率的学習課題を用いたものとし て位置づけられる。このような RDoCマトリックスと 個々の研究の対応付けを通して, 必ずしも診断マニュ アルにもとづく参加者の分類をしなくとも, 基礎研究 の立場から精神医学に貢献できる可能性がある。また, 計算論モデリングにより, 直接観測することが難しい 潜在的な過程やその個人差を推定することも可能とな り, RDoC の枠組みの中で行動や生理活動の動的な側 面を関連づけていくことも可能になると考えられる。

\section{引用文献}

Patrick, C. J., \& Hajcak, G. (2016). Reshaping clinical science: Introduction to the Special Issue on Psychophysiology and the NIMH Research Domain Criteria (RDoC) initiative. Psychophysiology, 53, 281-285.

Katahira, K. et al. (2014). Individual differences in heart rate variability are associated with the avoidance of negative emotional events. Biological Psychology, 103, 322-331. 